\title{
O HUMOR NO TEXTO JORNALÍSTICO POPULAR
}

\author{
Ana Rosa Ferreira Dias*
}

Esta comunicação tem por objetivo arrolar aspectos que caracterizam a manifestação da comicidade em textos da imprensa popular, mais especificamente, no jornal Notícias Populares, de São Paulo.

Em estudos anteriores (Dias, 1996) ${ }^{1}$, a propósito do discurso da violência no jornal popular, foi possível identificar uma freqüente presença do humor presidindo a elaboração das notícias. Esse toque de humor à fatalidade das tragédias noticiadas leva os leitores do diário a contactar com uma violência filtrada pela comicidade, o que, do ponto de vista da crítica, institui a violação de princípios éticos que asseguram respeito ao sofrimento humano, seja ele agressor, vítima ou audiência.

Independentemente da consideração de que a junção humor/horror constitua um "estado de violência", interessa-nos verificar como o humor se manifesta na imprensa popular.

De modo geral, é matéria do risível, nesse diário, não propriamente o crime, a morte, o fracasso em si, fatos esses avessos ao riso, mas o modo como tais acontecimentos são relatados e representados no discurso da notícia.

A linguagem do noticiário, cuidadosamente elaborada, faz irromper o riso do leitor em inesperadas manchetes que se valem de metáforas gírias, frases feitas, modificação de expressões familiares, similaridades sonoras, neologismos etc.

Em títulos como:

* USP e PUC-SP.

1 DIAS, A. R. F. (1996) O discurso da violência: as marcas da oralidade no jornalismo popular. São Paulo: EDUC/Cortez. 


\section{"Apagaram dois no meio do blecaute"}

(NP, 13 mar. 1999)

$\mathrm{e}$

"Pedreiro demolido a tiros"

(NP, 04 jul. 1991)

os verbos "apagar" e "demolir", opções metafóricas gírias, realizadas no paradigma do verbo "matar", quando relacionados, respectivamente, a "blecaute" e "pedreiro" sinalizam a presença do humor, tornado possível pela escolha lexical motivada em campos semânticos específicos. $\mathrm{O}$ jogo de palavras, que surpreende o leitor, evoca o lúdico, instante súbito de revisão da dor.

Para Riffaterre (1989: 147)², o humor pode estar presente em todos os gêneros e pode ser visto como:

"Desvio de expressão, modificação global dos componentes de uma frase ou de um texto, fenômeno de orientação da decodificação que desconcerta e diverte o leitor, catacrese que institui uma defasagem entre uma forma divertida e um conteúdo que não é divertido (neutro, grave, até mesmo trágico) ou entre uma forma insólita e um conteúdo que, no uso, exclui a extravagância de expressão."

O humor no texto jornalístico não se restringe a colunas ou seções específicas, de modo que não podemos falar propriamente em restrições temáticas, estilísticas ou lexicais. Mas, é um humor particular, que deve ser compreendido dentro da especificidade do gênero em que se manifesta.

2 RIFFATERRE, M. (1989) A produção do texto. Trad. Eliane F. P. Lima de Paiva. São Paulo: Martins Fontes. 